\title{
Comparative analysis of internal and external factors on profits in conventional and Islamic bank systems for the long and short terms in the 2013-2019 period
}

\author{
E.P.D. Anggoro \& A.K. Wardini \\ Universitas Terbuka, South Tangerang, Indonesia \\ M.E. Siregar \\ Indonesian Banking Development Institute, Jakarta, Indonesia
}

\begin{abstract}
Commercial banks comprise conventional commercial banks (CCB) and Islamic commercial banks (ICB). They use different principles; ICB uses Islamic principles, while CCB uses conventional principles. Therefore, there are also differences in how they earn profits and the internal and external factors that influence it. This research employs the error correction model and difference test. The samples of CCB and ICB were recorded in the 2013-2019 Indonesian Banking Survey and the Islamic Banking Survey. The research results reveal that CCB did not make provisions, so that profits remained high, but it had an impact on financing expenses from non-performing loan (NPL) for the next year. Meanwhile, ICB made backups, and so the profit earned reduced, but it had a lighter financing expenses from non-performing financing (NPF), so that the continuity/sustainability of ICB was better maintained.
\end{abstract}

\section{INTRODUCTION}

\subsection{Research background}

According to Kasmir (2008, p.25), a bank is a financial institution that serves the public by collecting funds, channeling the funds back to the public, and providing other bank services. Based on Law No. 10 of 1998 regarding banking, there are two types of banks, namely, commercial banks and rural banks. Commercial banks comprise conventional commercial banks (CCB) and Islamic commercial banks (ICB). In collecting, storing, and distributing funds, banks need operational funds. Bank operational funds are drawn from the money deposited by customers, funds from investors, and profits.

According to Horne and Wachowicz (2005, p. 235), return on assets (ROA) measures the overall effectiveness in generating profits through the available assets; in other words, it is the power of generating returns on invested capital. In 2015, the commercial banks' ROA reached their lowest point due to the crisis experienced by Greece in 2015, which was a continuation of the 2008 crisis. This was caused by debts that matured in June 2015 to the IMF amounting to 243 billion Euros (Pane, 2016). As a result of this failure of payments, Greece went into bankruptcy, while currently carrying out its business using borrowed money. This incident forced the Greek government to tighten capital controls in order to prevent a rush of cash outflow (Wirabrata, 2015). In addition, this crisis was exacerbated by high levels of non-performing loans (NPL) at banks in Greece in 2015, where the NPL value reached 35.6\% (Aggelopoulos and Georgepoulus, 2016).

For the Indonesian economy, this crisis caused a weakening of the exchange rate in 2015; it reached $10.89 \%$ (Wirabrata, 2015). Moreover, this crisis was also affected by inflation (Wirabrata, 2015). In June and July 2015, the inflation experienced by Indonesia was $7.26 \%$, and this inflation rate was the highest throughout 2015. Decline in gross domestic product (GDP) also led to 
the decline in the commercial banks' ROA. The decline in average GDP growth per quarter in 2014 reached $0.12 \%$, which caused a decrease in the commercial banks' ROA by $1.15 \%$ in 2014 . According to Macroeconomic Dashboard (2014), it was caused by slowing GDP growth in the mining and quarrying sector as well as industry. The slowdown in GDP growth indicates a decline in economic activity, which affects the ability of debtors to repay loans (bad credit), and it can affect bank profits.

In addition to external factors, ROA fluctuations are also influenced by internal factors. One of the internal factors affecting the ROA of CCB and ICB is the soundness of the bank. In Indonesia, to find out the health level of the bank, CCB refers to the Bank Indonesia Regulation No. 13/1/PBI/2011 regarding the Rating System for Commercial Banks, while for ICB refers to the Financial Services Authority Regulation No. 8/POJK.03/2014 regarding Assessment of Soundness Level of Sharia Commercial Banks and Business Units. In both regulations, the indicators used in assessing the soundness level of a bank consist of risk profile, good corporate governance (GCG), profitability (earnings), and capital. The better the management of risk management, GCG, profitability, and capital owned by the bank, the better placed the bank in generating profits. In addition, there are several other variables linked to bank profits, such as the bank size in terms of total assets. According to Kosmidou (2008), banks with large total assets are more profitable than banks with small total assets due to a large level of efficiency in generating profits.

\subsection{Literature review}

The grand theory in this research is the productive theory of credit. Halem (in Taswan, 2006) argued that bank liquidity will be guaranteed if productive assets are obtained from short-term loans that are easier to disburse during the normal business condition. In this theory, the bank focuses on providing short-term loans through repayment (installments) of the credit as a source of liquidity. This installment payment is also used as capital. This theory was chosen as the main theory, considering that banks need capital to generate profits.

\subsubsection{Differences between $C C B$ and ICB}

ICB has a difference in the interest system used compared to CCB. CCB uses the interest rate system, while the ICB uses the profit-sharing system (Ascarya, 2005). ICB adopts this system because interest rates contain elements of usury, which are prohibited by Islam. According to Islamic laws, the interest system has an element of injustice because the borrower is required to pay more than the loan without paying attention to the advantages/disadvantages of the borrower. On the other hand, the profit-sharing system used by Islamic banks is a system where the borrower and lender share the risks and benefits in the agreement, so that both parties do not feel disadvantaged in this case. This difference shows how CCB and ICB generate profits.

\subsection{Method}

The sample of this research was the aggregate data of CCB and ICB available in Indonesian Banking Statistics (SPI, Statistik Perbankan Indonesia, and SPS, Statistik Perbankan Syariah), which were taken from January 2013 to December 2019. The independent variables consist of internal factors (credit risk, liquidity risk, profitability, capital, and total assets) and external factors (inflation, exchange rates, and GDP). The analysis technique used the error correction model (ECM) and difference tests.

\section{RESULT}

\subsection{CCB analysis}

The variables that significantly affected the ROA of CCBs in the long-term equation are capital adequacy ratio (CAR), net interest margin (NIM), total assets, and middle exchange rates. The 
CAR negatively affected the ROA of CCBs; the CAR increased in conditions where capital growth was faster than the growth in the risk-weighted asset (RWA). With the increase in RWAs, even if they are lower than the capital increase, banks experience an increase in risk; so they need to add allowance for impairment losses (CKPN, Cadangan Kerugian Penurunan Nilai) to deal with these risks. The addition of CKPN by the bank shows that the bank incurs a fee, causing a decrease in profit/return. However, after correcting the imbalance of the CAR variable in this long-term equation, the short-term equation for the CAR variable became insignificant.

Furthermore, NIM negatively affected the ROA of CCBs when the increased NIM caused by the growth of net interest income was faster than the growth of productive assets. However, an increase in RWAs was also followed by the increase/growth of productive assets. With the increase in RWAs, there was an increase in risk, which led banks to make an allowance in the form of CKPN. Therefore, the issuance of fees for the CKPN could reduce bank profits/returns.

Furthermore, total assets positively affected the ROA of CCBs. This result is in accordance with that reported by Kosmidou (2008), who observed that a bank with large total assets has a larger economy of scale than a bank with small total assets, and thus, the bank will operate efficiently to generate higher and better profits.

Finally, the middle rate negatively affected the ROA when the depreciation of the Rupiah exchange rate affected the increase in the price of imported goods. This could cause an increase in production costs, which affected the ability of customers to repay loans/credits, and hence, this affected bank profits.

\subsection{ICB analysis}

The variables that significantly affected the ROA of ICBs in the long-term equation are financingto-deposit ratio (FDR), non-performing financing (NPF), and total assets. FDR positively affected the ROA of ICBs when the FDR increased, which indicated that the bank was expanding to finance funds to customers in the form of productive and consumptive financing. With the expansion of financing channeled carefully, the profit or return of the bank will automatically also be higher.

Furthermore, NPF negatively affected the ROA of ICBs. When the NPF was high, the bank added the allowance in the form of CKPN. In other words, the bank incurred additional costs for CKPN to not reduce the profit earned for financing provisions.

Furthermore, total assets positively affected the ROA of ICBs. This result is in accordance with that reported by Kosmidou (2008), who observed that a bank with large total assets has a larger economy of scale than a bank with small total assets, and thus the bank will operate efficiently to generate higher and better profits.

Based on the short term, the variables that significantly affected the ROA of ICBs were nonperforming financing (NPF) and the middle exchange rate. NPF still negatively affected the ROA of ICBs, so the cause was still the same. Meanwhile, the middle exchange rate negatively affected the ROA of ICBs when the exchange rate weakened (depreciation). This was caused by an increase in the price of imported goods, because of which production costs increased and the ability of customers to repay loans decreased, leading to the decline in bank profits. The difficulty of repaying loans could be exacerbated if the debtor borrowed funds in the form of US\$ because the exchange rate of Rp/US\$ was getting weaker, so that the value of credit repayments increased.

\subsection{Differences between CCBs and ICBs}

Overall, the difference between CCBs and ICBs lies in the interest system used by CCBs, which is the interest rate system, while ICBs adopt a profit sharing system. In other words, the methods of obtaining profits used by these two banks are different; CCB relies more on interest and ICB relies more on profit sharing (Ascraya, 2005, p.1). Moreover, the underlying asset is not followed by the customer. For example, a customer borrows funds from CCBs to buy a house; then the loan provided is in the form of cash. However, the customer can later use the funds for other purposes, even if the house purchase is not realized. Unlike the CCB, when a customer applies for financing 
to buy a house, the ICB will find a house for the customers, so they will receive a house instead of cash. Based on the Wilcoxon test, it is concluded that $\mathrm{H} 0$ was rejected; thus, there was a difference between the average ROA of CCBs and ICBs. This result also shows that CCBs and ICBs were different in managing profits. CCBs tended not to make provisions in the form of CKPN, so that profits remained high but affected the financing expenses from NPL in the further year. Meanwhile, ICBs would have a backup in the form of CKPN to reduce the profit earned by them, but they had less financing expenses from NPF, which affected the continuity/sustainability of ICBs.

\section{CONCLUSION AND SUGGESTION}

\subsection{Conclusion}

The internal and external factors had influences, both long-term and short-term, on the ROA of CCBs and ICBs. However, several different factors influenced it partially; the ROA of CCBs was influenced by CAR, NPL, NIM, exchange rate, and total assets, while the ROA of ICBs was influenced by FDR, NPF, exchange rate, and total assets. Based on these results, it can be concluded that a different handling is needed in managing earnings.

In addition, this research revealed that there was a difference in the average value of ROA between CCBs and ICBs based on the results of different tests, which were supported by the research results, in which CCBs and ICBs were different in managing profits. CCBs tended not to make provisions in the form of CKPN, so that profits remained high but affected the financing expenses from NPL in the further year. Meanwhile, ICBs would have a backup in the form of CKPN to reduce the profit earned by them, but they had less financial expenses from NPF, which affected the continuity/sustainability of ICBs.

\subsection{Suggestion}

For further research, it is necessary to find a replacement variable that is not partially significant between the two banks, namely, GDP, which may be replaced by per capita income, or inflation, which is replaced by the consumer price index or to create a new composite index. Furthermore, the policymakers at the national level do not make rules that equalize between CCBs and ICBs because these two types of banks have different ways of generating profits.

\section{REFERENCES}

Aggelopoulos, Eleftherios, and Antonios Georgopoulos. (2016). Bank Branch Efficiency under Environmental Change: a Bootstrap DEA on Monthly Profit and Loss Accounting Statements of Greek Retail Branches. European Journal of Operational Research, Volume 261, Issue 3: p.1170-1188.

Ascarya, and Diana Yumanita. (2005). Seri Kebanksentralan No. 14 Bank Syariah: Gambaran Umum. Jakarta: Bank Indonesia

Fajari, Slamet, and Sunarto. (2017). Pengaruh CAR, LDR, NPL, BOPO Terhadap Profitabilitas Bank (Studi Kasus Perusahaan Perbankan Yang Tercatat di Bursa Efek Indonesia Periode Tahun 2011 Sampai 2015). Proceeding at Seminar Nasional Multi Disiplin Ilmu \& Call for Papers Unisbank Ke-3:.853-862.

Horne V. James, and John M Wachowicz. (2005). Prinsip-prinsip Manajemen Keuangan (Fundamental of Financial Management). 12th eds. Translated by Dewi Fitriasari. Jakarta: Salemba Empat.

Kosmidou, K. (2008). The Determinants of Banks' Profits in Greece during The Period Of EU Financial Integration. Managerial Finance, 34(3): 146-159.

Pane, Boy Yusuf. (2016). Kegagalan Yunani Memanfaatkan Bailout dalam Upaya Mengatasi Krisis Ekonomi Tahun 2018. Jurnal Online Mahasiswa Fakultas Ilmu Sosial dan Ilmu Politik, Vol 3, No. 1: 1-12.

Taswan. (2006). Manajemen Perbankan. Yogyakarta: UPP STIM YPKP

Wirabrata, Achmad. (2015). Krisis Yunani dan Turbulensi Ekonomi Indonesia. Info Singkat Ekonomi dan Kebijakan Publik Vol VII No. 13/I/P3DI/Juli/2016: 13-16. 